\title{
Effects of lactation stage, lactation order and udder types on udder traits and composition of milk in Tuj ewes
}

\author{
Mehmet SARI $^{1}$, İsa YILMAZ ${ }^{2}$, Kadir ÖNK ${ }^{3}$ \\ ${ }^{1}$ Mehmet Akif Ersoy University, Veterinary Medicine Faculty, Department of Animal Science, Burdur; ${ }^{2}$ Iğdır University, Faculty of \\ Agriculture, Department of Animal Science, Iğdır; ${ }^{3}$ Kafkas University, Kars Vocational College, Department of Crop and Animal \\ Production, Kars, Turkey.
}

Summary: The present study was undertaken to assess the influences of lactation stage, lactation order, and udder types on udder traits and chemical composition of milk in Tuj sheep. Udder circumference (UC), udder depth (UD), udder bottom height (UBH), udder upper height (UUH) and udder width (UW) were significantly affected by lactation stage $(\mathrm{P}<0.01, \mathrm{P}<0.001)$. The effects of lactation order on udder measurements and chemical composition of milk and a udder type on chemical composition of milk were found to be not significant $(\mathrm{P}>0.05)$. UW was significantly affected by udder type $(\mathrm{P}<0.05)$. Fat, solid non fat (SNF), density, lactose and mineral was significantly affected by lactation stage $(\mathrm{P}<0.05, \mathrm{P}<0.001)$. Significant positive correlations $(\mathrm{P}<0.05, \mathrm{P}<0.01, \mathrm{P}<0.001)$ were established between UC with each of UD (0.41 and 0.52$)$, UW (0.62 and 0.68$)$ and teat diameter (TD) $(0.35$ and 0.40$)$ and between UD with each of TD (0.42 and 0.41) and UW (0.53 and 0.54) and also between teat length (TL) and TD (0.37 and 0.37); TD and UW (0.42 and 0.42); UBH and UUH (0.49 and 0.49); UUH and UW (0.37 and 0.36) at the 70 and 100 days of the lactation. The strongest positive correlations were found between SNF with each of density (0.92 and 0.96$)$, lactose (0.95 and 0.96), and mineral (0.98 and 0.99) at the 70 and 100 days of the lactation. The results of the study indicate that the influence of lactation stage on some udder traits and chemical composition of milk are very important and ought to be taken in to account in sheep breeding.

Key words: Chemical composition, lactation order, lactation stage, Tuj ewes, udder traits, udder type.

Tuj koyunlarında meme özellikleri ve sütün kompozisyonuna laktasyon evresi, laktasyon sırası ve meme tipinin etkisi

Özet: Bu araştırma, Tuj koyunlarında meme özellikleri ve sütün kimyasal kompozisyonuna laktasyon evresi, laktasyon sırası ve meme tipinin etkisini belirlemek amacıyla yapılmıştır. Laktasyon evresinin meme çevresi, meme derinliği, meme alt ve üst yüksekliği ile meme genişliğine etkisi istatistiki olarak önemli bulunmuştur $(\mathrm{P}<0.01, \mathrm{P}<0.001)$. Laktasyon sırasının meme ölçüleri ve sütün kimyasal kompozisyonuna etkisi ve meme tipinin sütün kimyasal kompozisyonuna etkisi istatistiki olarak önemsiz tespit edilmiştir ( $\mathrm{P}>0.05)$. Meme tipinin meme genişliğine etkisi ise istatistiki olarak önemli olmuştur $(\mathrm{P}<0.05)$. Laktasyon evresinin sütteki yağ, yağsız kuru madde, yoğunluk, laktoz ve minerale olan etkisi istatistiki olarak önemli tespit edilmiştir $(\mathrm{P}<0.05, \mathrm{P}<0.001)$. Laktasyonun 70 ve 100. günlerinde meme çevresinin; meme derinliği (0.41 ve 0.52$)$, meme genişliği (0.62 ve 0.68$)$ ve meme çap1 (0.62 ve 0.68$)$, meme derinliğinin; meme çapı ( 0.42 ve 0.42$)$ ve meme genişliği (0.53 ve 0.54$)$ ile meme uzunluğu ve meme çap1 (0.37 ve 0.37 ); meme çap1 ve meme genişliği (0.42 ve 0.42$)$; meme alt yüksekliği ve meme üst yüksekliği (0.49 ve 0.49$)$; meme üst yüksekliği ve meme genişliği (0.37 ve 0.36$)$ arasında önemli derecede pozitif yönde korelasyonlar belirlenmiştir $(\mathrm{P}<0.05, \mathrm{P}<0.01$, $\mathrm{P}<0.001)$. Laktasyonun 70 ve 100. günlerinde en güçlü pozitif korelasyonlar yağsız kuru madde ile yoğunluk (0.92 ve 0.96$)$, yağsiz kuru madde ile laktoz ( 0.95 ve 0.96$)$ ve yağsız kuru madde ile mineral (0.98 ve 0.99$)$ arasında tespit edilmiştir. Sonuç olarak, laktasyon evresinin bazı meme özellikleri ve sütün kimyasal kompozisyonuna etkisinin olduğu ve koyun yetiştirmede dikkate alınması gerektiği önemi ortaya çıkmıştır.

Anahtar sözcükler: Kimyasal kompozisyon, laktasyon dönemi, laktasyon sırası, meme özellikleri, meme tipi, Tuj koyunu.

\section{Introduction}

Dairy sheep production is a significant sector of livestock production in Turkey. Milk from sheep is widely used in the Turkey for making cheese and other dairy products. Approximately 93.85\% of Turkey's sheep population (29 284247 heads) are native breeds. Sheep milk (1 101013 t) is an important to milk production amounting to $6.04 \%$ of the total milk production (18 $223712 \mathrm{t}$ ) of Turkey. The Tuj breed is one of native sheep breeds of Turkey. There are 321052 heads of sheep in Kars (27). The Tuj breed is raised in throughout the north-east of Turkey generally for mutton and milk production. Breeders are not normally willing for expenses of any supplementation and almost never 
use supplement but hay. Therefore, performance of the sheep depends on the conditions of pasture and hay (26).

There are several factors which may affect udder traits and chemical composition in dairy ewes, therefore, these include breed, order and stage of lactation, weight, size, body condition, animal and udder sanitary state, breeding system and udder types (25). Accordingly, milk composition is very important because it affects the quality and determines the ratio processed product/milk and therefore the cost. The milk composition (water, lactose, fat, proteins and minerals) have many beneficial traits. For example; lactose is a valuable nutrient, because it increases intestinal absorption of calcium, magnesium and phosphorus, the utilization of Vitamin D, and favorably affects the intestinal flora (5).

There is a lot of research on the udder traits and composition of sheep milk in Turkey $(2,14,28,30)$. However, their effect on udder types and chemical composition of Tuj breed ewes have never been assessed and reported. Objectives of this study were to describe udder traits and chemical composition of Tuj breed ewes and to assess some factors which can affect them. Moreover, another objective was to detect correlations among various udder traits and chemical compositions.

\section{Materials and Methods}

This experiment was conducted at the Application and Research Farm of the Faculty of Veterinary Medicine, Kafkas University in 2013. A total of 52 ewes (average live weight of $50 \mathrm{~kg}$ ) were used in the experiment. All ewes were identified by ear tag. Ewes were lambed during April. At 30 days of postpartum, ewes had access to barley ( $250 \mathrm{~g}$ per ewe per day) in addition to ad libitum hay. Then, ewes were grazed on pasture during day-time when weather conditions permitted. The lambs were allowed to suckle their mothers continuously. Ewes were kept in a sheepfold at nights. The data for the udder measurements at $70^{\text {th }}$ and $100^{\text {th }}$ days of lactation were calculated by interpolation methods. Udder circumference (UC) was measured circumference of the largest area of the udder by measuring tape. Udder depth (UD) was measured in rear distance between the abdominal wall and the udder cleft. Teat length (TL) was measured on both sides from teat base until teat orifice. Teat diameter (TD) was measured in the largest of the teat. Udder upper height (UUH) was vertically measured from the perineum to the ground. Udder bottom height (UBH) was vertically measured from the bottom of the udder to the ground. Udder width (UW) was measured at the largest of the udder. Width, depth, upper height and bottom height of udder were determined with measuring stick, while teat measurements were taken by caliper. Udder types were determined as Type I, II, III and IV (18).
Individual samples of milk for chemical analyses were taken from Tuj ewes twice during lactation period (70-100 days). The ewes were hand-milked every morning. Aseptic milk samples (total $25 \mathrm{ml}$ ) from each udder half were collected in sterile tubes. The samples were analyzed immediately. Determination of somatic cell count in milk samples: was measured by using DCC (DeLaval Somatic Cell Measuring Device) to determine somatic cell count of the collected milk samples. After dropping a few drops from milk samples into De Laval count kit, loaded cassette was put into Delaval cell counter. The milk samples were not diluted. DCC counted somatic cells colored with DNA specific fluorescent probe Propidium Iodide. Amount of somatic cell count appeared as numerically visible on its screen in a minute (3). The chemical compositions of milk: such as fat, solid non fat (SNF), density, lactose, mineral and protein were determined by using a Lacto Star Ultrasonic Milk Analyzer machine.

It was assumed that there was no significant interaction among factors affecting udder traits and chemical composition of milk. Effects of factors such as lactation stage, lactation order and udder type on udder traits (UC, UD, TL, TD, UUH, UBH, UW), somatic cell count (SCC), and chemical composition (fat, SNF, density, lactose, mineral and protein) of Tuj sheep milk were analyzed in a repeated measurements on animals and analyzed using Least Squares Mixed Model Procedures of SPSS statistic package program. Analysis of correlations among all of the udder traits and chemical composition variables were performed (4).

\section{Results}

Least square means of udder circumference, udder depth, teat length, teat diameter, udder bottom and udder upper height and udder width of Tuj sheep are presented in Table 1. The traits of UC, UD, UBH, UUH and UW were significantly affected by lactation stage $(\mathrm{P}<0.05$, $\mathrm{P}<0.001)$. The effect of lactation order on udder measurements was found to be not significant $(\mathrm{P}>0.05)$. Least square means of SCC, fat, SNF, density, lactose, mineral and protein content of Tuj sheep milk are presented in Table 2. The traits of fat, SNF, density, lactose and mineral significantly were affected by lactation stage $(\mathrm{P}<0.05, \mathrm{P}<0.001)$. The effect of lactation order and udder type on chemical composition of milk were found to be not significant $(\mathrm{P}>0.05)$.

Coefficients of phenotypic correlation between udder traits and chemical composition of milk at the $70^{\text {th }}$ and $100^{\text {th }}$ days of lactation were given in Table 3 . Significant positive correlations $(\mathrm{P}<0.05, \mathrm{P}<0.001)$ were established between udder circumference and udder depth, udder circumference and teat diameter, udder circumference and udder width, udder depth and teat 
Table 1. Least squares means for the udder traits of Tuj ewes $(\mathrm{cm})$.

Tablo 1. Tuj koyunlarının meme özelliklerine ait en küçük kareler ortalamaları $(\mathrm{cm})$.

\begin{tabular}{ccccccccc}
\hline $\begin{array}{c}\text { Factor } \\
\text { General }\end{array}$ & $\mathrm{n}$ & $\mathrm{UC}$ & $\mathrm{UD}$ & $\mathrm{TL}$ & $\mathrm{TD}$ & $\mathrm{UBH}$ & UUH & UW \\
& 52 & $34.33 \pm 0.66$ & $13.59 \pm 0.31$ & $2.41 \pm 0.09$ & $1.17 \pm 0.03$ & $35.96 \pm 0.61$ & $46.87 \pm 0.36$ & $10.89 \pm 0.31$ \\
\hline Lactation stage (day) & & $* * *$ & $* * *$ & $\mathrm{NS}$ & $\mathrm{NS}$ & $* *$ & $* * *$ & $* * *$ \\
70 & 52 & $37.32 \pm 0.82$ & $14.59 \pm 0.31$ & $2.51 \pm 0.09$ & $1.18 \pm 0.03$ & $34.76 \pm 0.61$ & $45.63 \pm 0.36$ & $11.08 \pm 0.25$ \\
100 & 52 & $31.33 \pm 0.55$ & $12.59 \pm 0.31$ & $2.31 \pm 0.09$ & $1.16 \pm 0.03$ & $37.16 \pm 0.61$ & $48.11 \pm 0.36$ & $10.71 \pm 0.24$ \\
Lactation order & & $\mathrm{NS}$ & $\mathrm{NS}$ & $\mathrm{NS}$ & $\mathrm{NS}$ & $\mathrm{NS}$ & $\mathrm{NS}$ & $\mathrm{NS}$ \\
2 & 12 & $33.68 \pm 1.14$ & $13.51 \pm 0.55$ & $2.32 \pm 0.15$ & $1.15 \pm 0.05$ & $35.90 \pm 1.07$ & $46.58 \pm 0.63$ & $10.81 \pm 0.53$ \\
3 & 29 & $33.22 \pm 0.81$ & $13.37 \pm 0.39$ & $2.56 \pm 0.11$ & $1.20 \pm 0.04$ & $36.15 \pm 0.76$ & $46.93 \pm 0.45$ & $10.71 \pm 0.38$ \\
4 & 11 & $36.67 \pm 1.52$ & $13.98 \pm 0.73$ & $2.33 \pm 0.21$ & $1.16 \pm 0.07$ & $35.80 \pm 1.42$ & $47.19 \pm 0.84$ & $11.26 \pm 0.71$ \\
Udder type & & $\mathrm{NS}$ & $\mathrm{NS}$ & $\mathrm{NS}$ & $\mathrm{NS}$ & $\mathrm{NS}$ & $\mathrm{NS}$ & $*$ \\
1 & 11 & $33.79 \pm 1.30$ & $13.72 \pm 0.62$ & $2.44 \pm 0.18$ & $1.19 \pm 0.06$ & $35.86 \pm 1.22$ & $46.82 \pm 0.72$ & $10.63 \pm 0.60 \mathrm{ab}$ \\
2 & 13 & $33.41 \pm 1.11$ & $12.94 \pm 0.53$ & $2.40 \pm 0.15$ & $1.14 \pm 0.05$ & $35.68 \pm 1.04$ & $46.41 \pm 0.61$ & $9.81 \pm 0.51 \mathrm{~b}$ \\
3 & 17 & $34.29 \pm 1.48$ & $13.65 \pm 0.71$ & $2.35 \pm 0.20$ & $1.08 \pm 0.07$ & $36.45 \pm 1.38$ & $46.86 \pm 0.81$ & $10.97 \pm 0.69 \mathrm{ab}$ \\
4 & 11 & $35.64 \pm 1.28$ & $14.08 \pm 0.61$ & $2.47 \pm 0.17$ & $1.28 \pm 0.06$ & $35.83 \pm 1.20$ & $47.38 \pm 0.70$ & $12.07 \pm 0.59 \mathrm{a}$ \\
\hline
\end{tabular}

UC: Udder circumference (Meme çevresi), UD: Udder depth (Meme derinliği), TL: Teat length (Meme başı uzunluğu),

TD: Teat diameter (Meme başı çapı), UBH: Udder bottom height (Meme alt yüksekliği), UUH: Udder upper height

(Meme üst yüksekliği), UW: Udder width (Meme genişliği).

NS (Non Significant): $\mathrm{P}>0.05, *: \mathrm{P}<0.05, * *: \mathrm{P}<0.01, * * *: \mathrm{P}<0.001$.

$\mathrm{a}, \mathrm{b}$ : Means with unlike letters within the same column differ significantly $(\mathrm{P}<0.05)$.

a, b: Aynı sütunda farklı harfleri taşıyan ortalamalar arası farklılıklar önemlidir $(\mathrm{P}<0.05)$.

Table 2. Least squares means for the chemical composition of milk in Tuj ewes.

Tablo 2. Tuj koyunlarında sütün kimyasal kompozisyonuna ait en küçük kareler ortalamaları.

\begin{tabular}{ccccccccc}
\hline Factor & $\mathrm{n}$ & $\mathrm{SCC}\left(\mathrm{x} 10^{3} / \mathrm{ml}\right)$ & Fat (\%) & SNF (\%) & Density (g/ml) & Lactose (\%) & Mineral (\%) & Protein (\%) \\
General & 52 & $201.30 \pm 60.94$ & $9.06 \pm 0.24$ & $9.38 \pm 0.13$ & $1.030 \pm 0.001$ & $4.68 \pm 0.11$ & $0.75 \pm 0.01$ & $3.94 \pm 0.04$ \\
\hline Lactation stage (day) & & $\mathrm{NS}$ & $*$ & $* * *$ & $* * *$ & $* * *$ & $* * *$ & NS \\
70 & 52 & $266.10 \pm 97.65$ & $8.42 \pm 0.36$ & $9.76 \pm 0.19$ & $1.032 \pm 0.001$ & $5.07 \pm 0.17$ & $0.78 \pm 0.02$ & $3.87 \pm 0.05$ \\
100 & 52 & $136.40 \pm 37.10$ & $9.69 \pm 0.36$ & $9.00 \pm 0.15$ & $1.028 \pm 0.001$ & $4.29 \pm 0.13$ & $0.71 \pm 0.01$ & $4.00 \pm 0.03$ \\
Lactation order & & $\mathrm{NS}$ & $\mathrm{NS}$ & $\mathrm{NS}$ & $\mathrm{NS}$ & $\mathrm{NS}$ & $\mathrm{NS}$ & $\mathrm{NS}$ \\
2 & 12 & $292.42 \pm 106.00$ & $9.16 \pm 0.42$ & $9.27 \pm 0.22$ & $1.029 \pm 0.001$ & $4.65 \pm 0.20$ & $0.74 \pm 0.02$ & $3.85 \pm 0.07$ \\
3 & 29 & $176.24 \pm 74.95$ & $9.37 \pm 0.30$ & $9.47 \pm 0.16$ & $1.030 \pm 0.001$ & $4.74 \pm 0.14$ & $0.75 \pm 0.02$ & $3.95 \pm 0.05$ \\
4 & 11 & $113.10 \pm 141.33$ & $8.52 \pm 0.56$ & $9.40 \pm 0.30$ & $1.030 \pm 0.001$ & $4.62 \pm 0.26$ & $0.74 \pm 0.03$ & $4.02 \pm 0.09$ \\
Udder type & & $\mathrm{NS}$ & $\mathrm{NS}$ & $\mathrm{NS}$ & $\mathrm{NS}$ & $\mathrm{NS}$ & $\mathrm{NS}$ & $\mathrm{NS}$ \\
1 & 11 & $140.40 \pm 120.58$ & $9.31 \pm 0.48$ & $9.38 \pm 0.25$ & $1.029 \pm 0.001$ & $4.65 \pm 0.22$ & $0.74 \pm 0.02$ & $3.97 \pm 0.07$ \\
2 & 13 & $309.82 \pm 102.83$ & $8.70 \pm 0.41$ & $9.33 \pm 0.22$ & $1.030 \pm 0.001$ & $4.70 \pm 0.19$ & $0.74 \pm 0.02$ & $3.86 \pm 0.06$ \\
3 & 17 & $184.90 \pm 137.11$ & $9.10 \pm 0.55$ & $9.37 \pm 0.29$ & $1.030 \pm 0.001$ & $4.65 \pm 0.25$ & $0.74 \pm 0.03$ & $3.95 \pm 0.09$ \\
4 & 11 & $149.64 \pm 118.74$ & $9.21 \pm 0.47$ & $9.43 \pm 0.25$ & $1.030 \pm 0.001$ & $4.70 \pm 0.22$ & $0.75 \pm 0.02$ & $3.97 \pm 0.07$ \\
\hline
\end{tabular}

SCC: Somatic cell count (Somatik hücre sayıs1), SNF: Solid non fat (Yağsız kuru madde).

NS (Non Significant): $\mathrm{P}>0.05, *: \mathrm{P}<0.05, * * *: \mathrm{P}<0.001$.

diameter, udder depth and udder width, teat length and teat diameter, teat diameter and udder width, udder bottom height and udder upper height, udder upper height and udder width at the $70^{\text {th }}$ and $100^{\text {th }}$ days of lactation. The strongest positive correlations were found between solid non fat and density (0.92 and 0.96), solid non fat and lactose (0.95 and 0.96$)$, solid non fat and mineral (0.98 and 0.99), lactose and density (0.90 and $0.88)$, density and mineral (0.91 and 0.91), lactose and mineral (0.99 and 0.99$)$ at the $70^{\text {th }}$ and $100^{\text {th }}$ days of lactation. Significant negative correlations at the $70^{\text {th }}$ and $100^{\text {th }}$ days $(\mathrm{P}<0.05, \mathrm{P}<0.001)$ were established between UD and UBH (-0.53), TD and UBH (-0.32). Also significant negative correlations at the $100^{\text {th }}$ day of lactation $(\mathrm{P}<0.05, \mathrm{P}<0.001)$ were established between fat and SNF (-0.50), fat and density (-0.67), fat and lactose $(-0.34)$, fat and mineral $(-0.37)$, fat and protein $(-0.52)$. 
Table 3. Phenotypic correlation coefficients between udder traits and chemical composition of milk at the $70^{\text {th }}$ and $100^{\text {th }}$ days of lactation.

Tablo 3. Laktasyonun 70 ve 100. günlerinde meme özellikleri ve sütün kimyasal kompozisyonu arasındaki fenotipik korelasyon katsayıları.

\begin{tabular}{|c|c|c|c|c|c|c|c|c|c|c|c|c|c|c|}
\hline Trait & $\mathrm{UC}$ & UD & $\mathrm{TL}$ & TD & $\mathrm{UBH}$ & UUH & UW & $\mathrm{SCC}$ & Fat & SNF & Density & Lactose & Mineral & Protein \\
\hline $\mathrm{UC}$ & & $0.41 * * *$ & $0.08^{-}$ & $0.35^{* *}$ & $-0.15^{-}$ & $0.19^{-}$ & $0.62 * * *$ & $-0.15^{-}$ & $-0.37 * *$ & $0.08^{-}$ & $0.16^{-}$ & $0.01^{-}$ & $0.02^{-}$ & $0.21^{-}$ \\
\hline UD & $0.52 * * *$ & & $0.17^{-}$ & $0.42 * *$ & $-0.53 * * *$ & $0.03^{-}$ & $0.53 * * *$ & $-0.03^{-}$ & $-0.19^{-}$ & $-0.19^{-}$ & $-0.06^{-}$ & $-0.22^{-}$ & $-0.22^{-}$ & $0.18^{-}$ \\
\hline TL & $0.04^{-}$ & $0.17^{-}$ & & $0.37 * *$ & $-0.22^{-}$ & $0.03^{-}$ & $0.04^{-}$ & $-0.11^{-}$ & $0.01^{-}$ & $-0.13^{-}$ & $-0.12^{-}$ & $-0.14^{-}$ & $-0.14^{-}$ & $0.04^{-}$ \\
\hline $\mathrm{TD}$ & $0.40^{* *}$ & $0.41 * *$ & $0.37 * *$ & & $-0.32 *$ & $0.11^{-}$ & $0.42 * *$ & $-0.18^{-}$ & $0.01^{-}$ & $-0.17^{-}$ & $0.15^{-}$ & $-0.22^{-}$ & $-0.20^{-}$ & $0.22^{-}$ \\
\hline UBH & $-0.19^{-}$ & $-0.53 * * *$ & $-0.22^{-}$ & $-0.32 *$ & & $0.49 * * *$ & $-0.05^{-}$ & $0.05^{-}$ & $0.09^{-}$ & $-0.10^{-}$ & $-0.09^{-}$ & $-0.10^{-}$ & $-0.09^{-}$ & $0.02^{-}$ \\
\hline UUH & $0.22^{-}$ & $0.03^{-}$ & $-0.03^{-}$ & $0.10^{-}$ & $0.49 * * *$ & & $0.37 * *$ & $-0.15^{-}$ & $0.12^{-}$ & $-0.20^{-}$ & $-0.20^{-}$ & $-0.19^{-}$ & $-0.20^{-}$ & $-0.01^{-}$ \\
\hline UW & $0.68 * * *$ & $0.54 * * *$ & $0.04^{-}$ & $0.42 * *$ & $-0.06^{-}$ & $0.36^{*}$ & & $-0.16^{-}$ & $-0.13^{-}$ & $-0.18^{-}$ & $-0.09^{-}$ & $-0.18^{-}$ & $-0.19^{-}$ & $0.004^{-}$ \\
\hline SCC & $-0.04^{-}$ & $0.06^{-}$ & $0.14^{-}$ & $-0.10^{-}$ & $-0.13^{-}$ & $-0.20^{-}$ & $-0.25^{-}$ & & $-0.10^{-}$ & $0.04^{-}$ & $0.06^{-}$ & $0.01^{-}$ & $0.04^{-}$ & $0.11^{-}$ \\
\hline Fat & $-0.11^{-}$ & $-0.24^{-}$ & $-0.19^{-}$ & $-0.04^{-}$ & $0.28 *$ & $0.30 *$ & $-0.02^{-}$ & $-0.45^{* * *}$ & & $-0.50 * * *$ & $-0.67 * * *$ & $-0.34 *$ & $-0.37 * *$ & $-0.52 * * *$ \\
\hline SNF & $0.26^{-}$ & $0.10^{-}$ & $-0.12^{-}$ & $0.12^{-}$ & $0.06^{-}$ & $0.02^{-}$ & $0.21^{-}$ & $-0.09^{-}$ & $0.27^{-}$ & & $0.96^{* * *}$ & $0.96^{* * *}$ & $0.98 * * *$ & $0.03^{-}$ \\
\hline Density & $0.32 *$ & $0.20^{-}$ & $-0.05^{-}$ & $0.15^{-}$ & $-0.05^{-}$ & $-0.09^{-}$ & $0.24^{-}$ & $0.07^{-}$ & $-0.13^{-}$ & $0.92 * * *$ & & $0.88 * * *$ & $0.91 * * *$ & 0.18 \\
\hline Lactose & $0.24^{-}$ & $0.05^{-}$ & $-0.04^{-}$ & $0.08^{-}$ & $0.06^{-}$ & $0.02^{-}$ & $0.14^{-}$ & $-0.01^{-}$ & $0.17^{-}$ & $0.95^{* * *}$ & $0.90 * * *$ & & $0.99 * * *$ & $-0.24^{-}$ \\
\hline Mineral & $0.25^{-}$ & $0.07^{-}$ & $-0.10^{-}$ & $0.09^{-}$ & $0.07^{-}$ & $0.03^{-}$ & $0.17^{-}$ & $-0.05^{-}$ & $0.25^{-}$ & $0.99 * * *$ & $0.91 * * *$ & $0.99 * * *$ & & $-0.14^{-}$ \\
\hline Protein & $0.09^{-}$ & 0.16 & $-0.24^{-}$ & $0.14^{-}$ & $0.01^{-}$ & $0.01^{-}$ & $0.24^{-}$ & $-0.24^{-}$ & $0.27^{-}$ & $0.17^{-}$ & $0.09^{-}$ & $-0.16^{-}$ & $0.03^{-}$ & \\
\hline
\end{tabular}

Correlations at the $70^{\text {th }}$ day of lactation below the diagonal, at the $100^{\text {th }}$ day of lactation are above the diagonal (Köşegenin altı laktasyonun 70. günündeki korelasyonlar, köşegenin üstü laktasyonun 100. günündeki korelasyonlar).

-: $\mathrm{P}>0.05, *: \mathrm{P}<0.05, * *: \mathrm{P}<0.01, * * *: \mathrm{P}<0.001$

\section{Discussion and Conclusion}

The mean result of udder circumference observed in the current study was similar to values reported in Karacabey Merino ewes, but lower than values observed in Tahirova and Kivircik ewes (2). The udder circumference and udder width diminished throughout lactation (udder bottom height and udder upper height increased throughout lactation), this reduction being particularly evident at $100^{\text {th }}$ day of postpartum. The present results of udder circumference and udder width were similar to those reported by Unal et al (28) and Martinez et al (16). Regarding some traits related to udder circumference, udder depth, udder width and teat length of the 2, 3 and 4 order of lactation in this study was lower than values reported in Istrian ewes (23). These differences might be due to differences in genetics and environment conditions. A insignificant effect of lactation order on udder circumference was determined in presented study, with sheep in fourth lactation having the largest udder circumference, udder depth and udder width. Mroczkowski and Borys (19) and Rovai et al (24) found that udder measurements (depth, width, and circumference) increased as lactation order increased, reaching the highest values in the third and the fourth lactation. The teat diameter of Tuj ewes was smaller than values reported in Chios, Chios $x$ White Karaman $B_{1}$ and Bafra $(17,20,28)$. In this study, the udder type did not affect udder measurements except for udder width. Nevertheless, Dogan et al (8) and Fernandez et al (11) reported that udder types effected some udder traits.
Various non-infectious factors had effects on SCC for sheep milk. The most significant of these factors were order of lactation, stage of lactation, time of year, herd and diurnal variation (12). The effect of lactation stage, order of lactation and udder type did not produce any significant effect on SCC. Similar results were reported by Othmane et al (21). In this study, SCC decreased with the stage and order of lactation. Whereas, SCC had been reported to increase with stage of lactation and parity ( 9 , 15).

Milk samples of Tuj ewes contained on mean results of $9.06 \%$ fat, $4.68 \%$ lactose and $3.94 \%$ protein. Milk fat obtained in the present study was higher than the values reported for Anatolian Merino ewes (7.31\%) by Dogan et al (8), Karakas-Akkaraman $(6.06 \%)$ by Yilmaz et al (29), Tuj ewes (6.65\%) by Aksoy et al (1) and Tuj ewes $(6.91 \%)$ by Karaoglu et al (13). At the $70^{\text {th }}$ day of lactation the content of milk fat was significantly lower with regard to the $100^{\text {th }}$ day of lactation stage. These results are in agreement with the results reported by Pavic et al (22).

In this study, the effect of lactation stage on the solid non fat (SNF) was found to be significant. But, the effect of lactation order and udder types were not significant. Milk samples of Tuj ewes contained on mean results of $9.38 \%$ SNF. In this study, SNF were detected lower than the values (11.41\%) reported for Red Karaman ewes by Celik and Ozdemir (6). While the effect of lactation order and udder types on the lactose were not significant, the effect of lactation stage was 
found to be significant. Milk lactose content at the $70^{\text {th }}$ day of lactation $(5.07 \%)$ was found higher than of the $100^{\text {th }}$ day $(4.29 \%)$. Similar to this results were reported by Dario et al (7) and Pavic et al (22).

In the present study, highest correlations coefficients at $70^{\text {th }}$ and $100^{\text {th }}$ day of lactation were observed between UC and UD, UC and TD, UC and UW, UD and TD, UD and UW, TL and TD, TD and UW, UBH and UUH, UUH and UW. Similar findings were reported by Altincekic and Koyuncu (2) and Fernandez et al (10).

Also, significant correlations were established between SNF and density, SNF and lactose, SNF and mineral, density and lactose, density and mineral, and lactose and mineral. Significant negative correlations were established between SCC and fat, fat and density and lactose and protein. In the present study, the correlation between lactose and fat content at the $100^{\text {th }}$ day of lactation milk was also significant. Similar findings were reported by Pavic et al (22) and Yilmaz et al (30). The differences between this study and other studies with regards to udder traits and chemical composition of milk might be due to maternal age, lactation order, lactation stage, feeding methods, care, hygiene conditions, milking shape and milking technique, number of lambs suckled, management practices and climatic conditions, lambing season, breed, using different models.

The results from this study indicate that udder traits were not influenced by udder types (except for udder width) and lactation order. Breed, flock, lactation order, and stage, udder types were important factors influencing chemical composition of sheep milk. In this study, fat, SNF, density, lactose and mineral significantly was effected by lactation stage. This study indicates that the chemical composition of Tuj sheep milk was not influenced by udder types and lactation order.

\section{References}

1. Aksoy AR, Kirmizibayrak T, Saatci M, Dalci MT (2001): Production traits of Tushin sheep. II. Milk and wool yield. Vet Bil Derg, 17, 123-126.

2. Altincekic SO, Koyuncu M (2011): Relationship between udder measurements and the linear scores for udder morphology traits in Kivirclk, Tahirova and Karacabey Merino ewes. Kafkas Univ Vet Fak Derg, 17, 71-76.

3. Anonymous (2008): DeLaval Cell Counter DCC. Available at: http://www.delaval.com.tr/Products/Milking/Cell-counterDCC/default.htm. Accessed September 10.

4. Anonymous (2013): SPSS for Windows, Release 16.0 Standard version. Copyright SPSS Inc.

5. Campbell JR, Marshall RT (1975): The Science of Providing Milk for Man. New York, NY, USA: McGrawHill Ryerson, Limited.
6. Celik S, Ozdemir S (2003): The variations of some chemical and physicochemical parameters of Morkaraman sheep milk during lactation. Ataturk Univ Ziraat Fak Derg, 34, 263-268.

7. Dario C, Laudadio V, Bufano G (1996): Caratterizzazione della pecora leccese. Latte, 20, 1266-1269.

8. Dogan S, Aytekin I, Boztepe S (2013): The relationships between udder types and udder characteristics, milk yield and components in Anatolian Merino sheep. Journal of Tekirdag Agricultural Faculty, 10, 58-69.

9. Dulin AM, Paape MJ, Schultze WD, Weinland BT (1983): Effect of parity, stage of lactation, and intramammary infection on concentration of somatic cells and cytoplasmic particles in goat milk. J Dairy Sci, 66, 2426-2433.

10. Fernandez G, Alvarez P, San Primitivo F, De La Fuente LF (1995): Factors affecting variation of udder traits of dairy ewes. J Dairy Sci, 78, 842-849.

11. Fernandez G, Baro JA, De La Fuente LF, San Primitivo F (1997): Genetic parameters for linear udder traits of dairy ewes. J Dairy Sci, 80, 601-605.

12. Gonzalo C, San Primitivo F (1998): Somatic cell counts in ewe's milk. Ovis, 56, 56.

13. Karaoglu M, Macit M, Aksoy A (2001): Milk production traits of Tushin sheep in semi-intensive conditions. Turk J Vet Anim Sci, 25, 249-253.

14. Kirmizibayrak T, Aksoy AR, Saatci M, Tilki M (2005): Milk yield and udder characteristics in Tuj and Morkaraman ewes and the relationships between them. Kafkas Univ Vet Fak Derg, 11, 11-15.

15. Luengo C, Sanchez A, Corrales JC, Fernandez C, Contreras A (2004): Influence of intramammary infection and non-infection factors on somatic cell counts in dairy goats. J Dairy Res, 71, 169-174.

16. Martinez ME, Calderon C, De La Barra R, De La Fuente LF, Gonzalo C (2011): Udder morphological traits and milk yield of Chilota and Suffolk Down sheep breeds. Chil J Agr Res, 71, 90-95.

17. Mavrogenis AP, Papachristoforou C, Lysandrides $\mathbf{P}$, Roushias A (1988): Environmental and genetic factors affecting udder characters and milk production in Chios sheep. Genet Sel Evol, 20, 477-488.

18. Mills O (1982): Practical Sheep Dairying. Thorsons Publishers Limited, Wellingborough.

19. Mroczkowski S, Borys B (1998): The morphology of the udder and milk quantity in the milking hybrid ewes $F_{1}$ East Friesian $x$ Polish Merino. In: Proc. 6th international symposium on the milking of small ruminants. Athens, Greece, pp. 406-408.

20. Mundan D, Ozbeyaz C (2004): Milk yield of White Karaman (WK), Klvirclk $x W K B_{1}$ and Chios $x W K B_{1}$ ewes and growth and livability of crossbred lambs. Lalahan Hay Arast Enst Derg, 44, 23-35.

21. Othmane MH, De La Fuente LF, Carriedo JA, San Primitivo F (2002): Heritability and genetic correlations of test day milk yield and composition, individual laboratory cheese yield, and somatic cell count for dairy ewes. J Dairy Sci, 85, 2692-2698.

22. Pavic V, Antunac N, Mioc B, Ivankovic A, Havranek JL (2002): Influence of stage of lactation on the chemical 
composition and physical properties of sheep milk. Czech J Anim Sci, 47, 80-84.

23. Prpic Z, Mioc B, Vnucec I, Drzaic V, Pavic V (2013): Non-genetic factors of udder morphology traits in Istrian ewes. Mljekarstvo, 63, 72-80.

24. Rovai M, Such X., Piedrafita J, Caja G, Pujol MR (1998): Evolution of mammary morphology traits during lactation and its relationship with milk yield of Manchega and Lacaune dairy sheep. In: Proc. 6th International symposium on the milking of small ruminants. Athens, Greece, pp. 63-65.

25. Rovai M (2001): Morphological and physiological traits that affect milkability in Manchega and Lacaune ewes. $\mathrm{PhD}$ Thesis, Faculdat de Veterinaria, Universitat Aut ${ }^{\prime}$ onoma de Barcelona, pp. 281.

26. Saatci M, Yildiz S, Kaya I (2003): New rearing systems for Tuj (Tushin) lambs. Small Rumin Res, 50, 23-27.

27. TUIK (2014): Turkish Statistical Institute. Livestock statistics. Available at: 14.07.2014, http://www.turkstat.gov.tr.
28. Unal N, Akcapinar H, Atasoy F, Yakan A, Ugurlu M (2008): Some udder traits and growth of lambs and phenotypic correlations between those of traits with milking traits and milk production measured by various milk estimation methods in Bafra sheep. Ankara Univ Vet Fak Derg, 55, 117-124.

29. Yilmaz O, Denk H, Arslan M (2003): Milk yield characteristics of Karakaş-Akkaraman ewes in extensive conditions. Vet Bil Derg, 19, 67-72.

30. Yilmaz O, Cak B, Bolacali M (2011): Effects of lactation stage, age, birth type and body weight on chemical composotion of Red Karaman sheep milk. Kafkas Univ Vet Fak Derg, 17, 383-386.

Geliş tarihi: 24.04.2014 / Kabul tarihi: 03.11.2014

\author{
Address for correspondence: \\ Assist. Prof. Dr. Mehmet Sarl \\ Mehmet Akif Ersoy University, \\ Veterinary Medicine Faculty, \\ Department of Animal Science, Burdur, TURKEY \\ e-mail:msari_40@hotmail.com
}

